
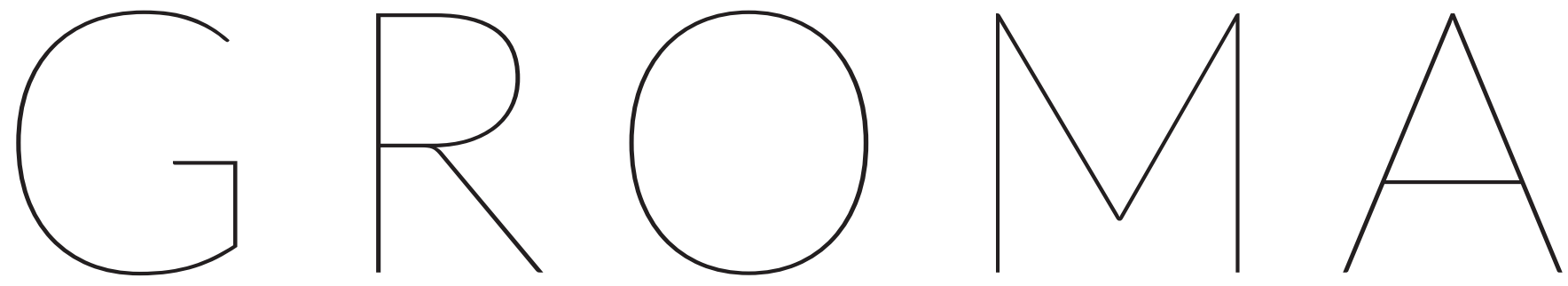

documenting archaeology | dept. of history and cultures, university of bologna

Open-Access E-Journal about methodology applied to archaeology http://groma.unibo.it

\title{
Francesco Pizzimenti
}

The Urban Archaeology Project in Asculum: the case of Piazza Arringo

Volume 3-2018

ISSN: $1825-411 \mathrm{X}$

pp. $1-10$

DOI: 10.12977/groma17

Publisher: BraDypUS [http://books.bradypus.net]

Publication date: 29/12/2018

License: CC BY-NC-ND 4.0 International

Section: Article 


\section{The Urban Archaeology Project in Asculum: the case of Piazza Arringo}

The work presented here is a brief summary of part of my post-graduate dissertation and falls within the Urban Archaeology Project of the University of Bologna in Asculum in agreement with the Archeological Superintendency of the Marche Region and the Municipality of Ascoli Piceno. During the 2013 campaign a non-intrusive survey was carried out in Piazza Arringo: the field data, after their collection and process, have been compared to previous archaeological knowledge coming from bibliographical and archival data in order to add them to the archaeological reconstruction of the city.

\section{Roman Asculum}

Ascoli Piceno is a city in the southern part of Marche and it has been continuously inhabited from the pre-Roman period until today. The reason for this fortune has to be connected to its geographical location, in fact it developed along the river Tronto's valley, a natural transport route that linked the Adriatic coast to the Apennines, through Gole del Velino to the Tiber's valley and then to the Tyrrhenian coast of Italy'. Knowing this, it is not surprising that one of the most important Roman roads, Via Salaria, was built along this pathway. Moreover the plain occupied by the historic settlement is almost entirely self-protected by some natural features such as the deeply recessed beds of the rivers Tronto and Castellano and the hill of the Annunziata. The first surround the plain on three sides, the second closes almost completely the remaining one leaving only a narrow entrance to the lowland. This tight corridor can be easily equipped with defensive structures as proved by the Picenum walls made with mighty sandstone blocks and then by the Roman walls in opus reticulatum in which Porta Gemina was opened.

Early mentions of Picentes's capital by written sources are linked to its anti-Gallic alliance with Romans at the beginning of the 3rd century BC and then to the rebellion of Picentes quelled by Rome in 267 $\mathrm{BC}^{2}$. Ascoli then became a civitas foederata until the beginning of the first century $\mathrm{BC}$ when it was the epicenter of the Social War. When in 89 BC the city surrendered to Pompeo Strabone's army it became a municipium and, probably during the Second Triumvirate, gained the form of government 
of a colony ${ }^{3}$. It is to this period that the shape of the Roman city that the latest archaeological investigations ${ }^{4}$ and studies ${ }^{5}$ have quite unanimously brought us can be related.

Although the trails of ancient roads and blocks can be read pretty easily in the modern urban fabric of the city centre and many aspects of the ancient city, such as the route followed by the two main roads and its modular plant, have been pointed out, some questions, for instance the location of the forum, are still unsolved ${ }^{6}$.

One area suspected to be the location of the Roman forum is the current Piazzo Arringo: whose name comes from the medieval period when Ascoli, after it had become a municipality, used it as place for town meetings called arenghi.

\section{Archaeological finds from Piazza Arringo}

Early news of archaeological findings from Piazza Arringo come from the end of the 19th century (1882) by Giulio Gabrielli, curator of the town's library and museum of antiquities: during the construction of a fountain in the eastern area of the square "in front of the middle window of the eastern wing of the Municipality building ${ }^{7}$, a floor paved in squared travertine's tiles was unveiled, a Northeast oriented wall in travertine blocks, a wall in little travertine blocks parallel to the first one and a Roman road paved in travertine blocks in the 2 meter wide space between the two walls. More findings were made in 1887 and 1889: in particular another paved road (probably the remains of a decumanus) was discovered in the space between Palazzo Panichi to the North and the fountain to the South, the path was constrained to the South by an East-West oriented wall in opus reticulatum ${ }^{8}$.

More recently, during some public works in the early 2000s, the archaeological investigation led by the Archaeological Superintendency of Marche has improved the knowledge of this archaeological context $^{9}$ (Fig. 1). The survey has shown that in Roman times the area was marked out by at least two roads $^{10}$ : an East-West decumanus along the track of the modern road and a North-South cardo, approximately located at the eastern fountain, where G. Gabrielli had already seen it. Both roads were paved in travertine slabs and the data coming from the dig have allowed us to assume their size to be 5.40 meters, the same as the decumanus maximus found under Via Mazzini, for the decumanus and 3.90 meters for the cardo".

More archaeological evidence was found in two limited digs done in the southern area: below the venue of Ente Quintana and in front of it, inside the square. The already mentioned roads ran around an open area bordered by a colonnade on all sides, whose western wing had a double aisle interrupted by a structure on a podium. In a later date the colonnade's northern wall was extended to the West by a structure in opus vittatum that barred the North-South road.

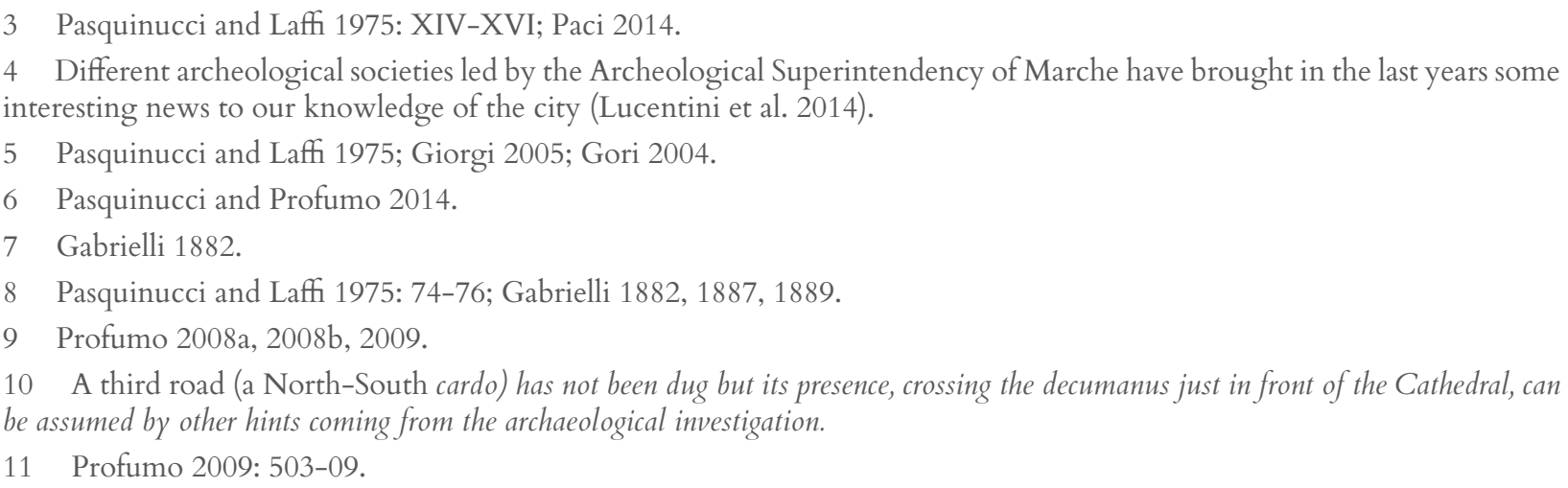



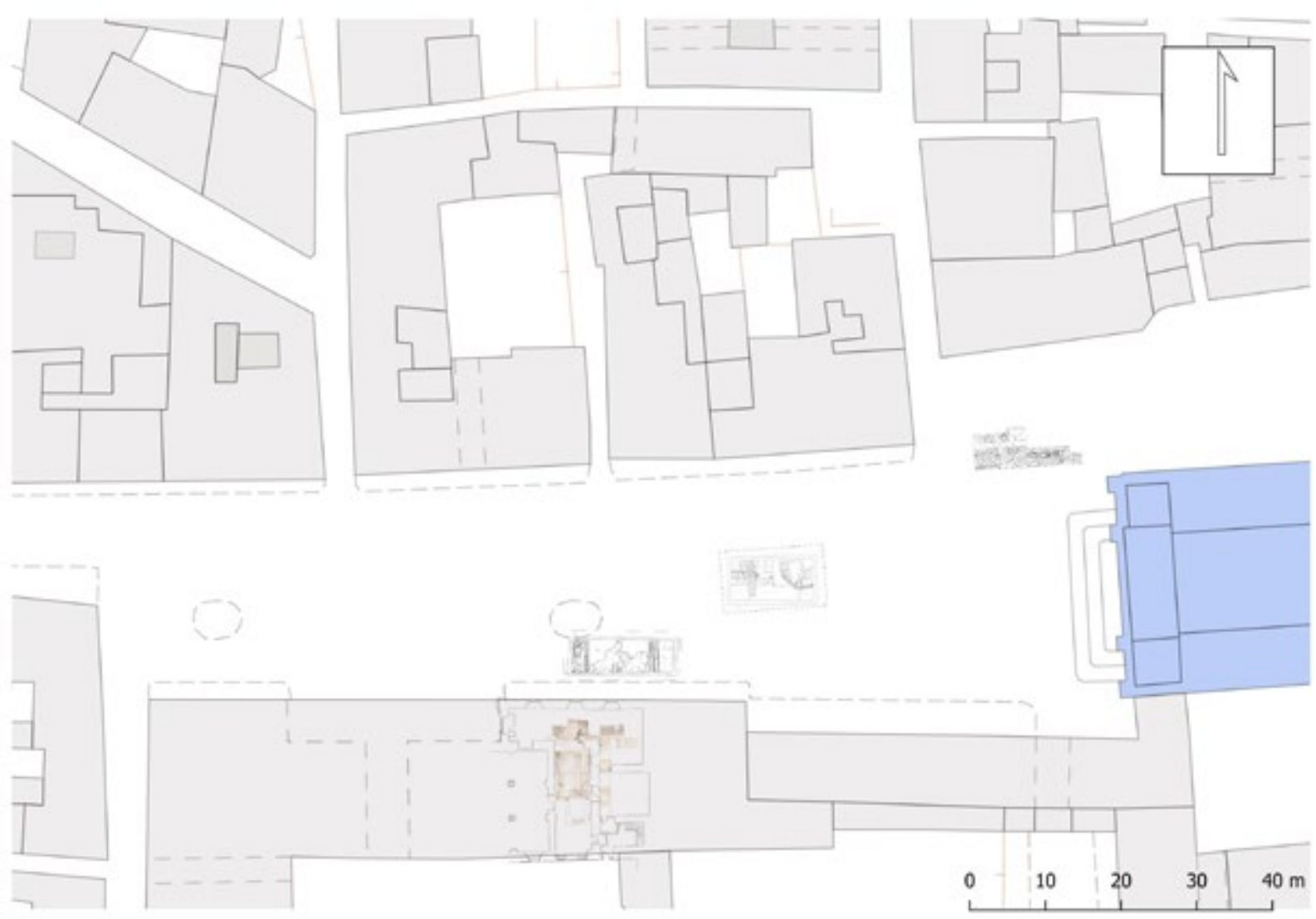

Fig. 1. Location of most relevant Superintendency's digs. Archaeological maps from Profumo 2009, georeferencing by the author.

\section{The non invasive survey: data collection and results}

In order to supplement this data with additional information, as part of the preventive archaeology project led by the University of Bologna in agreement with the Archaeological Superintendency of Marche and Ascoli Piceno's Municipality, during the 2013 campaign, Piazza Arringo's area has been examined using non invasive techniques ${ }^{12}$.

The main goals of these activities have been:

- verify the presence of buried findings that could be attributed to ancient structures occasionally discovered by previous archaeological digs;

- produce, through a total station, a topographical survey in order to locate a geophysical map on the base cartography provided by the Municipality of Ascoli Piceno.

Because of the nature of the urban context, Ground Penetrating Radar (GPR) technique was chosen instead of magnetometry in order to avoid the strong magnetic interference that usually affects urban areas: moreover the instrument used (IDS Hi-Mod 1), equipped with a double frequency antenna (600-200 MHz) allows, in ideal conditions, for a high resolution survey that can reach $5 \mathrm{~m}$ in depth ${ }^{13}$.

Field operations, in order to avoid a long occupation of a highly frequented area, were led through the creation of four different grids: three consecutive grids located in the central and eastern area of the square, and a last one placed in the clearing among Palazzo Panichi, the Baptistery and the Cathedral (Fig. 2).

12 Boschi 2016; Giorgi 2016.

13 For a brief introduction to the main geophysical techniques and GPR use in archaeology (Boschi 2009; Conyers 2009). 

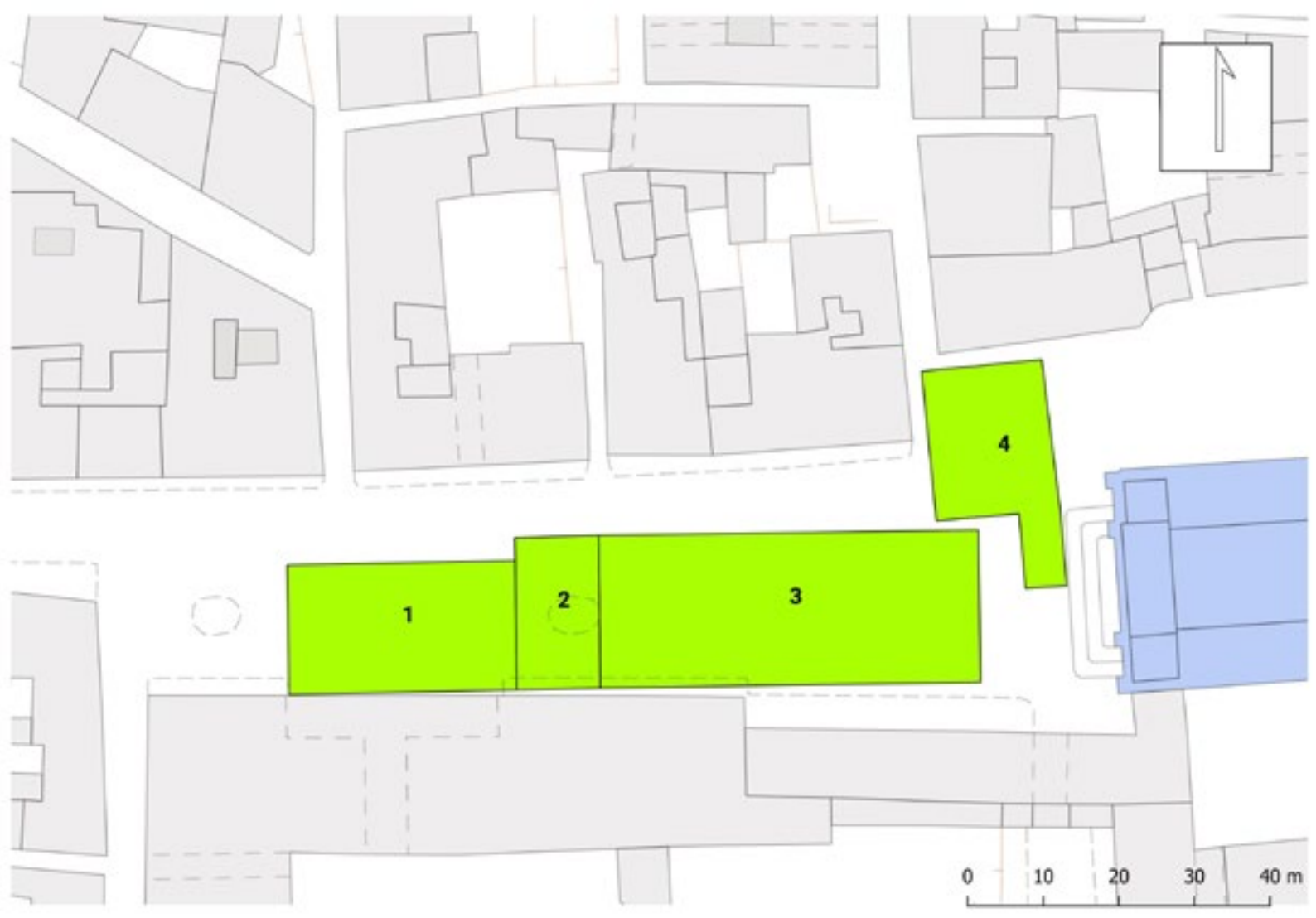

Fig. 2. GPR grids location

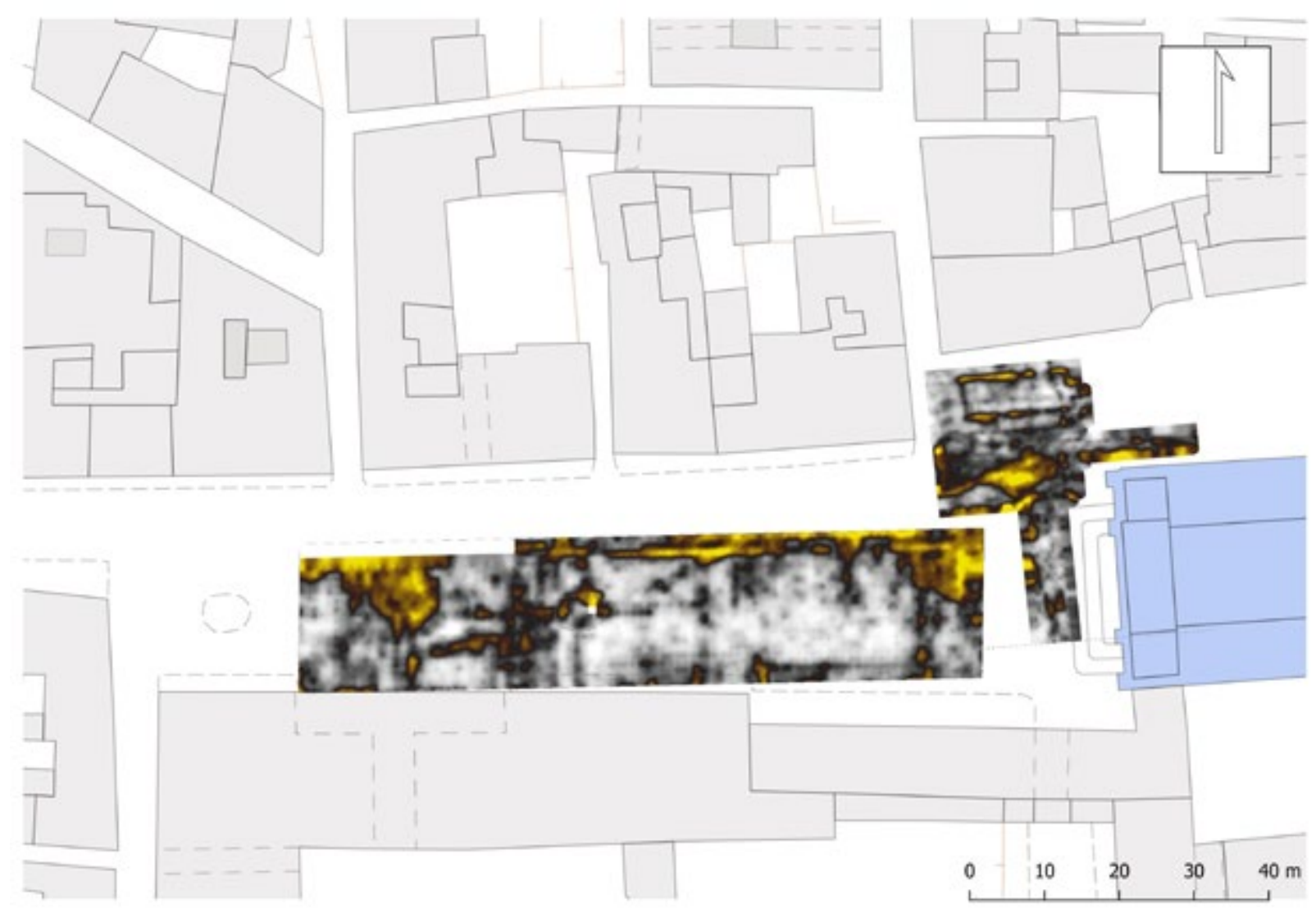

Fig. 3. GPR anomalies maps. 


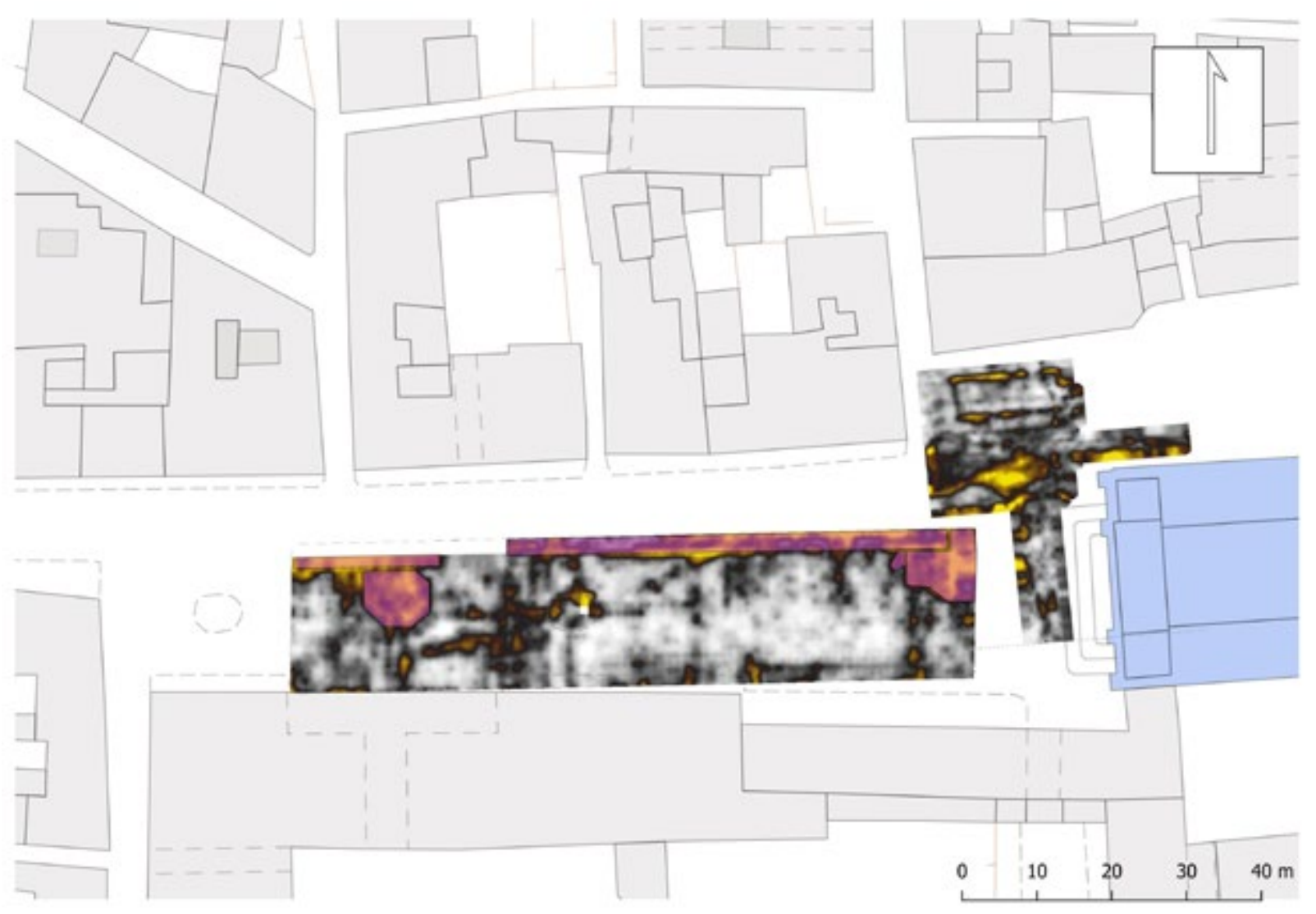

Fig. 4. Principal GPR anomalies that can be linked to modern structures.

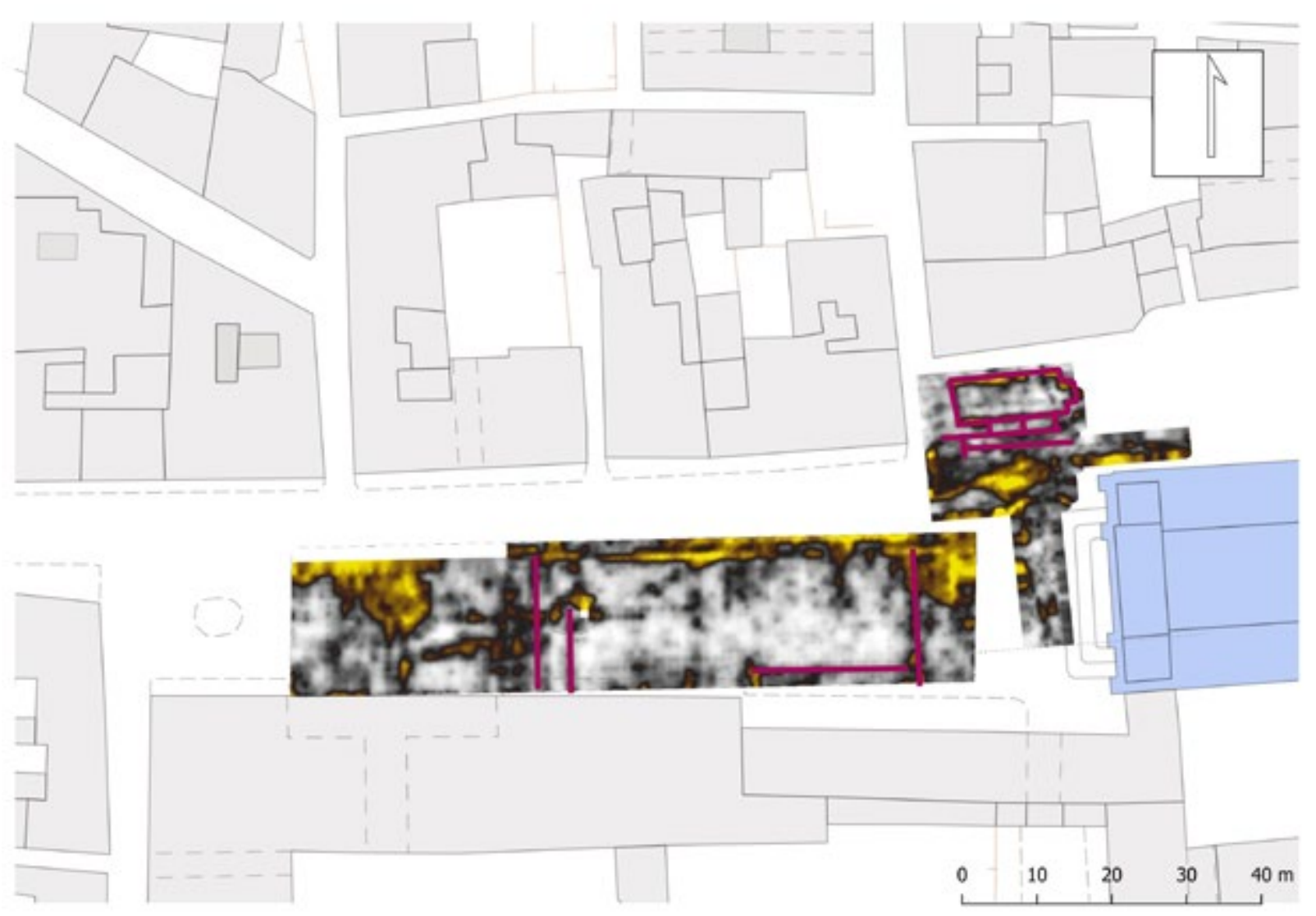

Fig. 5. Linear GPR anomalies linked to archaeological evidences. 
As can be easily gathered from Figure 2 almost all the square's surface was involved in the survey, the only uninspected areas were the western and the northern ones due to the presence of some obstacles (a fountain to the West and some commercial structures along the North edge of the square).

Following the survey, the data processing has highlighted a buried context really hard to understand due to a complex stratification already detected by the archaeological investigation of the square. In fact, as often happens in urban areas that have been continuously inhabited, both ancient and modern structures can be found buried.

In the central area of the square, where grids 1-3 were placed, the most interesting stratigraphic context was the one between 1.10 and $1.40 \mathrm{~m}$ depth. In grid 4, instead, the most responsive was the one between 0.55 and 0.80 meters. In both instances, different anomaly sources can be recognised, these usually reveal the buried presence of reflective elements (Fig. 3).

The central area is marked out, mainly in its northern half, by the presence of powerful geometrical discontinuity, that stands out on the map in black and yellow spots (Fig. 4).

These discontinuity, even though hard to read, can be ascribed to recent manipulation of the ground:

- The anomaly in the upper left corner of grid 1 seems to have a fairly geometrical shape, especially in the lower half. This octagonal shape can be linked quite certainly to the base of king Vittorio Emanuele's statue placed here by the Municipality between 1878 and 1882. The linear discontinuity that can be seen at the bottom and to the right of the octagon instead can be ascribed to the drainage and water pipes of the fountain that was replaced by the statue.

- Straight anomalies located in the upper zone of grids 2 and 3, despite at a first glance being linked to the colonnade's northern wall and its western extension, both seen by G. Gabrielli and an early 2000s archaeological investigation led by the Superintendency, should instead be identified as modern infrastructures and their trenching. Various data point in this direction, especially the distance from Palazzo Panichi's wall and the colonnade's northern wall. During the archaeological dig it was measured at $9.40 \mathrm{~m}$ and it does not match with the distance between Palazzo Panichi and the radar's data (approximately $13 \mathrm{~m}$ ). Furthermore, this distance can not even be linked to the inner wall of the colonnade found in the B trench made during the Superintendency's dig, in fact it is at least $3 \mathrm{~m}$ away from the discontinuity. A second option is that the radar's data could be linked to the remains of the colonnade's collapsed roof but its apparent lack in the findings from B trench makes it unconvincing. Other evidence against this option is that the anomaly seems to continue both to the West and East of the colonnade: if in the first case it can be explained by the wall in opus vittatum that in the late Roman ages extends the colonnade's wall, in the second there is no explanation coming from the archaeological dig. The most suitable option in this case is that the anomalies are coming from the sidewalks placed here before the renovation of the square.

- In the case of yellow anomalies at the center of the map, as displayed from the overlap between the CTR and the radar's marks, they can be ascribed to the structures and piping of the Eastern fountain.

The discontinuities that can be linked to archaeological structures, instead, are the black straight ones highlighted in purple (Fig. 5). The two parallels located on the left could be possibly connected to the edges of the Roman cardine and the others placed behind the left one can be read as structures linked to the road. The North to South alignment on the right instead can be related to the western wall of the colonnade. Much harder is the comprehension of the longitudinal anomaly in the lower part of the map. It can be thought of as an ancient structure that was placed in the square closed in by the colonnade or a more recent one, placed here when the monument had already lost its original function. 
Straight discontinuities are visible also in the clearing between Palazzo Panichi and the Baptistery. In the grid 4 area the perimeter of S. Biagio's church destroyed in 1882 is really well recognisable and other straight shapes that seem to connect to it: they could be successive structures that leant against the church's wall. It is very likely, indeed, that they could be the traces of the medieval graves found in this area during the archaeological exploration: the discontinuity can be linked in particular to the graves with travertine slab walls seen but not dug out during the archaeological survey and some previous public works ${ }^{14}$.

Lastly, the big yellow spot that can be seen under these straight discontinuities, although it does not have a well defined shape, could be related to the track of the Roman decumano found here by the Superintendency's archaeological dig. In this case the irregular shape could be produced by the postRoman activities that have involved a road route as often happens in the late Roman-medieval period ${ }^{15}$.

\section{A reconstructive suggestion of the area}

On the basis of the information collected from both archaeological digs and a non intrusive survey, it is possible to reconstruct a space occupied by a monumental square bordered, on all its sides ${ }^{16}$, by an colonnade. The colonnade's western wing, measuring approximately $8 \mathrm{~m}$, has been verified to have a double aisle with a row of columns in the middle; the norther one, instead, on the base of excavation data proposed during the exhibition "Archeologia di una piazza" seemed to be narrower and with only one aisle. This kind of architectural development can be mirrored and applied to the East and South wings getting a structure that can be compared to some well known porticus, such as the Porticus Metelli in Rome.

The entrance to the colonnade was granted by an opening in the northern wall of the colonnade, along the decumanus. This opening, found during the archaeological dig of a trench, was not at the center of the wall but slightly shifted to the East corresponding roughly with the door of Palazzo Panichi. The opening was then closed, maybe when the northern wall of the colonnade was extended towards the West blocking the cardo bordering the West wing of the colonnade and reaching the corner of the Roman block ${ }^{17}$.

The early 2000's archaeological dig of the area as also uncovered the NW corner of a structure on a podium that interrupted the West wing of the colonnade. On the basis of the information gathered from the archaeological dig, it is not possible to specify what kind of building it was but, given the monumentality of the remains, it can be assumed it had a public function. The structure was made of travertine blocks joined by masonry in opus coementicium covered in opus mixtum, set on a carved frame and originally coated in travertine slabs. As it was already assumed ${ }^{18}$, the blocks, according to a well known Roman building technique ${ }^{19}$, were used as foundations for columns in monumental building such as temple or colonnades.

\footnotetext{
14 Profumo 2005: 858.

15 Profumo 2005: 858; Staffa 1996: 343-44, 2006: 349-50.

16 The presence of the West and North wings has been verified by the archaeological digs; the eastern one, although it has not been explored, can be reconstructed on the basis of the continuation to south of the northern wall. Even though we have no evidence of the South wing, its existence can be reasonably argued.

17 Profumo 2008b: 62, 2009: 510.

18 Profumo 2009: 509.

19 Giuliani 2006: 125.
} 
In order to reconstruct the type of building, it is useful to notice that the North edge of the carved base continues beyond the structure just described reaching the N-S cardo. As already noted ${ }^{20}$, this occurrence can be linked to the presence of a stairway that led to the top of the podium and then to the fairly simple identification of the building with a temple. Although this could be the most immediate identification for a building resting above the podium, another option could be viable. In fact, presuming the existence of the staircase, in the case of a temple it would have the entrance directly on the road: a not so common situation in Roman architecture. In this case the temple would also have also its back to the square that would make the architectural composition of the complex (square, porticus, temple) and its use not so functional.

A reasonable option could be that the building was instead a monumental entrance to the square: this can explain the presence of the staircase directly on the N-S cardo - in this case a specular stairway would have been on the East side of the podium, inside the square. Moreover, the identification of the structure with an entrance seems to be reasonable if we point out that at a certain moment the entrance on the North wing of the colonnade was definitely closed and the wall extended to the end of the block. In this case, given the information we have, there would be two closed areas that could be connected with this entrance. Unfortunately, the lack of archaeological data does not allow us to resolve the matter once for all.

This lack of evidence also makes it challenging to date the complex. In this case we can only rely on the carved base frame consisting of cyma recta topped by a quarter circle which was used in podium decoration in Rome from the end of the II century B.C. to the end of the I century B.C. ${ }^{21}$ In addition to this, in order to have a more close chronological range, it could be useful to look to the other carved base frames known in Ascoli, in particular the one from the ionic temple in San Venanzo Church that is dated to the third quarter of the first century B.C.22. On the basis of this evidence, it can be assumed that the construction of the monumental complex could have fallen into the general renovation of the town linked to the deduction of the triumviral colony, as the perfect fit to the modular scheme of the blocks seems to suggest (Figg. 6-8).

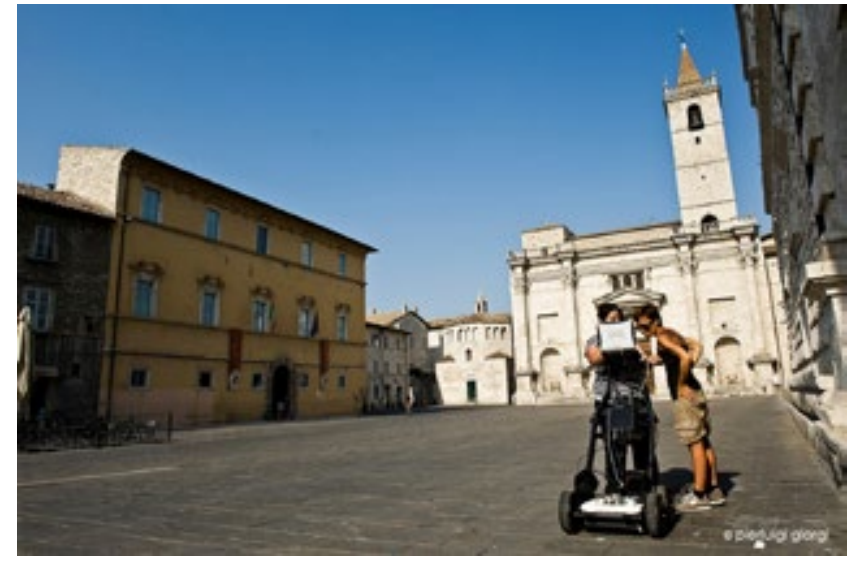

Fig. 6. GPR survey in Aringo square (photo by P.Giorgi)

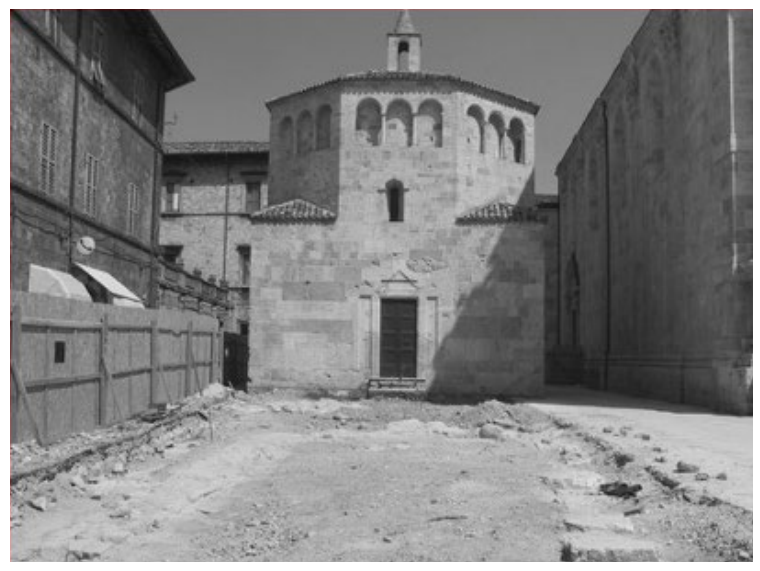

Fig. 7. The remains of San Biagio's church. 


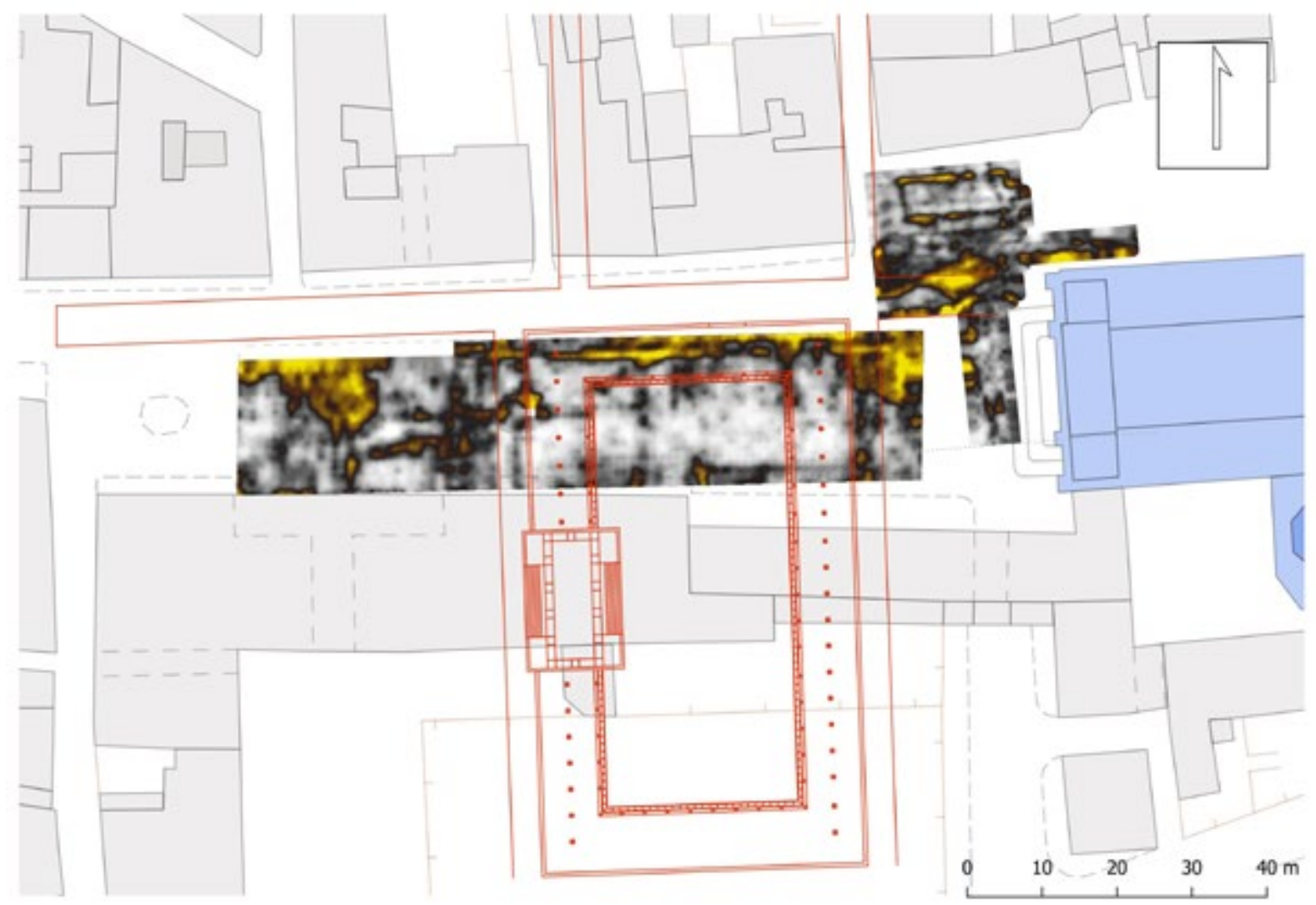

Fig. 8. Reconstructive hypotheses of the squared with porticoes in the Roman era

\section{Reference list}

Amadio, Adele Anna, Luigi Morganti, and Michele Picciolo, ed. 2008. La cattedrale di Ascoli Piceno. Napoli: M. D'Auria.

Boschi, Federica. 2009. 'Introduzione alla geofisica per l'archeologia'. In Groma 2. In profondità senza scavare: metodologie di indagine non invasiva e diagnostica per l'archeologia, 291-315. Bologna: BraDypUS.

. 2016b. 'Reading ancient cities. The contribution of the non-invasive techniques'. In Looking to the future, caring for the past: preventive archaeology in theory and practice: proceedings of the 20132014 Erasmus IP Summer Schools in Preventive Archaeology: evaluating sites and landscapes: methods and techniques for evaluating the archaeological value edited by F. Boschi, 85-100 Bologna: Bononia University Press.

Conyers, Lawrence B. 2009. 'Ground Penetrating Radar (GPR) per l'archeologia'. In Groma 2. In profondità senza scavare: metodologie di indagine non invasiva e diagnostica per l'archeologia, 359-71. Bologna: BraDypUS.

De Marinis, Giuliano, e Gianfranco Paci, ed. 2000. Atlante dei beni culturali dei territori di Ascoli Piceno e di Fermo. Beni Archeologici. Milano: Silvana.

Gabrielli, Giulio. 1882. Taccuini. 48.

1887. Taccuini. 52.

1889. Taccuini. 54. 
Giorgi, Enrico. 2000. 'La via consolare Salaria e le sue diramazioni nel territorio'. In Atlante dei beni culturali dei territori di Ascoli Piceno e di Fermo, 145-53. Beni Archeologici. Milano: Silvana.

2005. 'Riflessioni sullo sviluppo urbano di Asculum'. Ocnus 13: 207-28.

2016. 'City archaeology in the adriatic area: the cases of Burnum in Dalmatia and of Suasa and Ascoli in the Marche region'. In Looking to the future, caring for the past: preventive archaeology in theory and practice: proceedings of the 2013-2014 Erasmus IP Summer Schools in Preventive Archaeology: evaluating sites and landscapes: methods and techniques for evaluating the archaeological value, edited by F. Boschi, 101-23. Bologna: Bononia University Press.

Giuliani, Cairoli Fulvio. 2006. L'edilizia nell'antichità. Roma: Carocci.

Lucentini, Nora, Enrico Giorgi, Tommaso Casci Ceccacci, Marco Antognozzi, Serena Cesare, Michele Massoni, Mara Miritello, and Luca Speranza. 2014. 'Dall'archeologia alla storia. Note preliminare di archeologia urbana.' In Storia di Ascoli dai Piceni all'epoca romana edited by G. Paci, 411-29. Ascoli Piceno, Italy: Librati.

Shoe, Lucy. 1965. 'Etruscan and Republican Roman mouldings'. Memories of the American Accademy in Rome XXVIII.

Paci, Gianfranco. 2014b. 'L'organizzazione amministrativa della città romana'. In Storia di Ascoli dai Piceni all'epoca romana edited by G. Paci, 109-21. Ascoli Piceno: Librati.

Pasquinucci, Marinella, and Umberto Laffi. 1975. Asculum. I. Storia di Ascoli Piceno nell'età antica di Umberto Laffi - Studio sull'urbanistica di Ascoli Piceno romana di Marinella Pasquinucci. Pisa: Giardini.

Pasquinucci, Marinella, e Maria Cecilia Profumo. 2014. 'Ascoli Piceno: la città e l'organizzanione dello spazio urbano'. In Storia di Ascoli dai Piceni all'epoca romana edited by G. Paci, 123-69. Ascoli Piceno: Lìbrati.

Profumo, Maria Cecilia. 2005. 'Schede di archeologia altomedievale in Italia: Marche'. Studi Medievali, 3, XLVI (II): 843-914.

2008a. 'Gli scavi archeologici nel Battistero'. In La Cattedrale di Ascoli Piceno edited by A. A. Amadio, L. Morganti, and M. Picciolo, 78-80. Napoli: M. D’Auria.

2008b. 'Gli scavi e le principali testimonianze nell'area del Duomo'. In La Cattedrale di Ascoli Piceno edited by A. A. Amadio, L. Morganti, and M. Picciolo, 62-64. Napoli: M. D’Auria.

2009. 'La topografia di Asculum Picenum: nuovi dati'. In Omaggio a Nereo Alfieri: contributi all'archeologia marchigiana: atti del convegno di studi, Loreto 9-11 maggio 2005, 491-529. Roma:Tored.

Staffa, Andrea Rosario. 1996. 'Resti dell'antica Truentum - Castrum Truentinum. Martinsicuro, località Case Feriozzi.' In Le Valli del Vibrata e del Salinello, Documenti dell'Abruzzo teramano edited by F. Abbate, L. Franchi dell'Orto and C. Vultaggio, 332-54. Pescara: Carsa.

. 2006. 'I centri urbani dell'Abruzzo adriatico fra tarda antichità e alto medioevo.' In Le città italiane fra la tarda Antichità e l'alto Medioevo, Atti del convegno, Ravenna, 26-28 Febbraio 2004 edited by A. Augenti, 345-476. Firenze: All'Insegna del Giglio.

Visani, Fabio. 2007. 'Rilievo e studio del Tempio romano della chiesa di S. Venanzio ad Ascoli Piceno'. Groma 1. Archeologia tra Piceno, Dalmazia ed Epiro edited by E.Giorgi, E. Vecchietti, J. Bogdani, 157-160. Bologna: Ante Quem. 